\title{
PENERAPAN AKUNTANSI FORENSIK DAN AUDIT INVESTIGATIF TERHADAP MENDETEKSI KECURANGAN ( FRAUD )
}

\author{
Enika Diana Batubara, SE,M.Si \\ Universitas Amir Hamzah \\ enika_diana@yahoo.com
}

\begin{abstract}
Abstrak
Penelitian ini bertujuan untuk mengetahui dan menganalisis pengaruh penerapan akuntansi forensik dan audit investigatif terhadap mendeteksi kecurangan pada Kantor Akuntan Publik di Kota Medan. Penelitian ini menggunakan data primer yang diperoleh dari auditor Kantor Akuntan Publik di Kota Medan. Dari populasi, diambil secara convinience sampling dan ditarik sebesar 21 sample auditor dengan populasi sebanyak 21 orang auditor. Variabel penelitian ini terdiri dari akuntansi forensik dan audit investigatif sebagai variabel independen dan mendeteksi kecurangan sebagai variabel dependen. Hasil penelitian Secara parsial akuntansi forensik berpengaruhsignifikan terhadap mendeteksi kecurangan. Hal ini terlihat dari nilai $t_{\text {hitung }}>\mathrm{t}_{\text {tabel }}$ yaitu $2.114>2.10092$ dan nilai signifikansi pada variabel akuntansi forensik yang lebih kecil dari 0.05 (0.049< 0.05). Audit investigatif tidak berpengaruhsignifikan terhadap mendeteksi kecurangan. Hal ini terlihat dari nilai $t_{\text {hitung }}<\mathrm{t}_{\text {tabel }}$ yaitu $0.819<$ 2.10092 dan nilai signifikansi pada variabel audit investigatif yang lebih besar dari 0.05 yaitu $(0.424>0.05)$. Secara simultan pada variabel akuntansi forensik dan audit investigatif menunjukkan bahwa diperoleh $\mathrm{F}_{\text {hitung }}>\mathrm{F}_{\text {tabel }}(57.201>3.55)$ dengan nilai signifikansi lebih kecil dari $0.05(.000<0.05)$, yang artinya akuntansi forensik dan audit investigatif secara simultan atau bersama-sama memiliki pengaruh signifikan secara simultan terhadap mendeteksi kecurangan. Penelitian menggunakan data primer sehingga dapat diperoleh bahwa nilai $R$ Square menunjukkan nilai sebesar 0.864 atau sebesar $86.4 \%$ yang dapat diartikan bahwa pengaruh variabel independen (akuntansi forensik dan audit investigatif) terhadap variabel dependen (mendeteksi kecurangan) sebesar $86.4 \%$.
\end{abstract}

Keyword : Akuntansi Forensik, Audit Investigatif, Mendeteksi Kecurangan.

Jurnal Insitusi Politeknik Ganesha Medan 


\section{PENDAHULUAN}

Perkembangan dunia usaha pada saat ini yang semakin pesat tidak hanya membawa dampak bagi kemajuan dibidang ekonomi termasuk perkembangan dunia akuntansi, tetapi juga menjadi sumber bagi munculnya berbagai kecurangan (fraud). Praktik - praktik kecurangan yang terjadi merupakan suatu pukulan bagi dunia profesi akuntansi, karena dapat menimbulkan keraguan masyarakat terhadap fungsi dan peran akuntansi di masyarakat.Peran auditor dalam mendeteksi kecurangan - kecurangan yang terjadi masih belum optimal. Berbagai kecurangan masih saja terjadi dengan berbagai skala dan modus yang terkadang sulit untuk dideteksi dan dicegah. Hal inilah yang menuntut lahirnya akuntansi forensik dalam ilmu akuntansi.Akuntansi forensik diharapkan mampu untuk menjawab tantangan dunia akuntansi yang semakin kompleks dan membantu mengungkapkan berbagai kecuranganyang terjadi. Dalam mendeteksi fraud tidak hanya akuntansi forensik yang dibutuhkan untuk membedah kasus-kasus kecurangan. Pelaksanaan audit investigatif juga harus dilakukan untuk membuktikan adanya fraud yang kemungkinan terjadi. Istilah investigatif muncul dalam Undang-Undang No. 15 Tahun 2004 tentang Pemeriksaan Pengelolaan dan Tanggung Jawab Keuangan Negara yang menjelaskan bahwa "audit investigatif termasuk dalam pemeriksaan dengan tujuan tertentu, yaitu pemeriksaan yang dilakukan dengan tujuan khusus,diluar pemeriksaan keuangan dan kinerja."

\section{KAJIAN PUSTAKA}

Menurut Islahuzzaman (2012 : 156) "Kecurangan (fraud) adalah mencakup suatu ketidakberesan dan tindakan illegal yang bercirikan penipuan yang disengaja". Sebagai contoh dalam hal penyajian laporan keuangan, salah saji yang disengaja dapat diklasifikasikan sebagai kecurangan dalam pelaporan keuangan dan salah saji yang timbul dari perlakuan tidak semestinya terhadap aktiva. Menurut Tunggal (2016:1) "Kecurangan (Fraud) adalah Sebagai Konsep legal yang luas, kecurangan menggambarkan setiap upaya penipuan yang disengaja, yang dimaksudkan untuk mengambil aset atau hak orang atau pihak lain”. Menurut Hopwood, Leiner dan Young (2008 : 3), “Akuntansi forensik adalah aplikasi keterampilan investigasi dan analitik yang bertujuan untuk menyelesaikan masalah - masalah keuangan melalui cara - cara yang sesuai dengan standar yang ditetapkan oleh pengadilan dan hukum”. Menurut Wind (2014 :47) “Akuntansi forensik adalah salah satu cabang akuntansi yang secara khusus melakukan penyelidikan atau investigasi atas kasus kecurangan keuangan yang bersifat material". Dari beberapa pengertian akuntansi 
forensik diatas, dapat disimpulkan bahwa akuntansi forensik adalah penerapan disiplin akuntansi yang berdasarkan pada keterampilan-keterampilan dalam menginvestigasi dan menganalisis yang bertujuan untuk menyelesaikan masalah keuangan yang dilakukan berdasarkan peraturan-peraturan yang ditetapkan oleh hukum. Menurut Herlambang (2011 : 3) "Audit investigatif yaitu suatu bentuk audit atau pemeriksaan yang bertujuan untuk mengidentifikasi dan mengungkap kecurangan atau kejahatan dengan menggunakan pendekatan, prosedur atau teknik-teknik yang umumnya digunakan dalam suatu penyelidikan atau penyidikan terhadap suatu kejahatan." Dari beberapa pengertian diatas, dapat disimpulkan bahwa audit investigatif adalah proses pengumpulan dan pengujian bukti-bukti terkait kasus penyimpangan yang berindikasi merugikan keuangan Negara atau perekonomian Negara, untuk memperoleh kesimpulan yang mendukung tindakan litigasi atau tidakan korektif manajemen.

\section{METODE PENELITIAN}

\section{Lokasi Penelitian}

Lokasi penelitian dilakukan di KAP Hendrawinata Eddy Siddharta dan Tanzil.

\section{Populasi dan Sampel}

Menurut Sugiono (2012 : 115), Populasi adalah wilayah generalisasi yang terdiri dari obyek atau subyek yang mempunyai kualitas dan karakteristik tertentu yang ditetapkan oleh peneliti untuk dipelajari dan kemudian ditarik kesimpulannya. Populasi yang digunakan dalam penelitian ini adalah seluruh auditor yang ada di KAP Hendrawinata Eddy Siddharta dan Tanzil yaitu sebanyak 21 auditor. Menurut Sugiono (2012:115), sampel adalah bagian dari jumlah dan karakteristik yang dimiliki oleh populasi tersebut. Sampel yang digunakan dalam penelitian ini adalah sampel jenuh. Menurut Sugiono (2001:61), sampel jenuh adalah teknik penentuan sampel bila semua anggota populasi digunakan sebagai sampel. Sampel dari penelitian ini yaituseluruh auditor yang ada di Kantor Akuntan Publik Hendrawinata Eddy Siddharta dan Tanzil yaitu sebanyak 21 auditor

\section{Teknik Pengumpulan Data}

Teknik pengumpulan data yang digunakan pada penelitian ini adalah sebagai berikut :

1. Observasi, pengumpulan data primer yang diperoleh dari Kantor Akuntan Publik KAP Hendrawinata Eddy Siddharta dan Tanzil.

Kuesioner, metode dimana peneliti menyusun daftar pertanyaan secara teoritis yang

kemudian dibagikan kepada responden guna memperoleh data yang berhubungan dengan

kegiatan penelitian. Kuesioner ini diberikan kepada auditor yang menjadi pengguna sistem

informasi akuntansi..

Jurnal Insitusi Politeknik Ganesha Medan 


\section{DISCUSSION}

\subsection{Pengaruh Akuntansi Forensik Terhadap Mendeteksi Kecurangan}

Hipotesis 1 (pertama) penelitian ini yang menyatakan bahwa akuntansi forensik berpengaruh signifikan terhadap mendeteksi kecurangan. Berdasarkan hasil uji secara parsial (uji t) yang menunjukkan nilai thitung $>t_{\text {tabel }}$ yaitu $2.114>2.10092$ dan nilai signifikan sebesar 0,000 yang lebih kecil dari nilai $\alpha=0,05$ dan berkoefisien positif, yang berarti bahwa akuntansi forensik berpengaruh positif dan signifikan terhadap mendeteksi kecurangan. Berdasarkan hal tersebut, maka hipotesis 1 (pertama) pada penelitian ini dapat diterima. Dalam kaitan dengan hal tersebut dimana hal ini menggambarkan bahwa akuntansi forensikyang diterapkan dalam mengaudit bervariasi. Hasil ini memberikan bukti empiris bahwa akuntansi forensik berpengaruh signifikan dan positif terhadap mendeteksi kecurangan.

\subsection{Pengaruh Audit Investigatif Terhadap Mendeteksi Kecurangan}

Hipotesis 1 (pertama) penelitian ini yang menyatakan bahwa akuntansi forensik berpengaruh signifikan terhadap mendeteksi kecurangan. Berdasarkan hasil uji secara parsial (uji t) yang menunjukkan nilai $t_{\text {hitung }}<\mathrm{t}_{\text {tabel }}$ yaitu $0.819<2.10092$ dan nilai signifikan yang lebih besar dari nilai $\alpha=0,05$ yaitu $0.424<0.05$ yang berarti bahwa audit investigatif tidak berpengaruh positifterhadap mendeteksi kecurangan. Berdasarkan hal tersebut, maka hipotesis 2 (kedua) pada penelitian ini ditolak. Dalam kaitan dengan hal tersebut dimana hal ini menggambarkan bahwa audit investigatif dalam mempengaruhi mendeteksi kecurangan tidak bervariasi. Hasil ini memberikan bukti empiris bahwa audit investigatif tidak berpengaruh signifikan dan negatif terhadap tingkat pendeteksian kecurangan. Dengan demikian fenomena yang diperoleh pada awal penelitian, terjawab dengan hasil yang diperoleh pada penelitian ini. Dimana fluktuatifnya angka sanksi pajak dipengaruhi secara signifikan oleh tingkat pendeteksian kecurangan.

\subsection{Pengaruh Akuntansi Forensik dan Audit Investigatif terhadap mendeteksi kecurangan}

Hipotesis 3 (tiga) yang menyatakan akuntansi forensik dan audit investigatif secara simultan berpengaruh signifikan terhadap mendeteksi kecurangan. Berdasarkan hasil uji secara simultan pengaruh akuntansi forensik dan audit investigatif terhadap mendeteksi kecurangan. Berdasarkan hasil uji secara simultan (uji F) yang menunjukkan nilai $F_{\text {hitung }}<F_{\text {tabel }}$ yaitu $(57.201>3.55)$ dan diperoleh nilai signifikansi sebesar 0,000 yang lebih kecil dari nilai $\alpha=0,05$ dan berkoefisien positif. Artinya, akuntansi forensik dan audit investigatif berpengaruh positif dan signifikan terhadap mendeteksi kecurangan. Dengan demikian hipotesis 3 (ketiga) pada penelitian ini diterima. Dalam kaitan dengan hal tersebut dimana hal ini 
menggambarkan bahwa akuntansi forensik dan audit investigatif mempengaruhi pendeteksian kecurangan bervariasi. Hasil ini memberikan bukti empiris bahwa akuntansi forensik dan audit investigatif berpengaruh signifikan dan positif terhadap pendeteksian kecurangan. Dengan demikian fenomena yang diperoleh pada awal penelitian, terjawab dengan hasil yang diperoleh pada penelitian ini. Dimana fluktuatifnya angka akuntansi forensik dan audit investigatif dipengaruhi secara signifikan oleh tingkat pendeteksian kecurangan

\section{KESIMPULAN}

Berdasarkan pada penelitian yang telah dilakukan oleh peneliti, maka diambilah kesimpulan sebagai berikut:

1. Berkaitan dengan mendeteksi kecurangan (Y), maka dengan ini menyarankan agar kantor akuntan publik tersebut :

a. Semua auditor yang ada di KAP tersebut harus selalu mengawali pendeteksian dengan mengetahui dan melakukan analisa pola kecurangan yang mungkin terjadi.

b. Seluruh auditor harus melakukan sosialisasi kebijakan anti kecurangan, pelatihan anti kecurangan, dan evaluasi proses bisnis untuk menghindari kecurangan.

c. KAP harus melakukan atau mengadakan sosialisasi kepada seluruh auditor mengenai sanksi atas kecurangan. Sanksi itu dapat berupa pengurangan kompensasi, pemecatan bahkan proses hukum.

d. KAP harus melakukan evaluasi program anti kecurangan secara berkala dan mengambil langkah perbaikan secara terus menerus.

2. Berkaitan dengan variabel akuntansi forensik (X1), maka dengan ini menyarankan agar kantor akuntan publik tersebut :

a. Auditor harus bekerja secara optimal dan sadar akan tugasnya bahwa mereka harus menemukan kecurangan yang terjadi agar kecurangan tersebut dapat terdeteksi.

b. Kantor akuntan publik tersebut dapat melakukan pembentukan tim untuk para auditor agar proses pendeteksian kecurangan bisa lebih cepat dan tepat karena mereka akan bekerja sesuai tugasnya dalam tim. Jadi, proses tersebut tidak akan berlangsung lama.

c. Auditor membutuhkan teknik investigatif yang tepat, baik teknik yang disarankan oleh pihak KAP maupun teknik yang dilakukan sendiri oleh auditor tersebut. Hal itu berguna untuk memudahkan proses pendeteksian kecurangan.

d. Dalam melakukan pekerjaan, auditor harus melakukan hal yang berguna untuk mempermudah proses pendeteksian kecurangan sebagai contoh adalah melakukan wawancara.

e. Auditor harus melakukan analisis laporan keuangan yang mana hal tersebut adalah langkah yang harus di lakukan oleh para auditor.

f. Penggunaan computer adalah salah satu media yang akan memudahkan auditor dalam mendeteksi kecurangan jika auditor tersebut menggunakannya secara tepat dan sesuai kebutuhan. 
g. Auditor harus melakukan pengumpulan data dan dokumentasi bukti yang tepat dan akurat karena pengumpulan data dan dokumentasi bukti adalah aspek penting yang harus dilakukan oleh auditor agar dalam mendeteksi kecurangan yang terjadi lebih mudah untuk terdeteksi.

h. KAP harus selalu menghimbau kepada auditor untuk selalu membuat laporan hasil investigasi yang tepat sesuai bukti yang sudah terkumpul.

i. Auditor harus selalu melakukan langkah teknis pendekatan akuntansi forensik guna sebagai langka dalam mendeteksi kecurangan.

3. Berkaitan dengan variabel audit investigatif (X2), maka dengan ini menyarankan agar kantor akuntan publik tersebut :

a. Pihak KAP harus selalu mengingatkan auditor bahwa dalam mengaudit, auditor harus memeriksa fisik dan mengamati laporan keuangan dengan teliti.

b. Auditor harus selalu meminta atau mencarii nformasi dan mengkonfirmasi kebenaran adanya informasi tersebut yang telah didapatkan.

c. Auditor harus selalu melakukan review analitikal guna memudahkan pendeteksian kecurangan dan juga sebagai hal yang dapat meyakinkan keakuratan analisis tersebut.

d. Pihak KAP harus selalu mengingatkan para auditor untuk selalu melakukan penghitungan kembali untuk mencegah kesalahan penghitungan dalam mengaudit.

e. Auditor harus selalu membuat laporan akhir hasil audit guna sebagai dasar untuk memberikan rekomendasi perbaikan kepada pihak manajemen dan juga sebagai bahan untuk pertimbangan para auditor selanjutnya dalam mengevaluasi.

\section{Saran}

1. Bagi peneliti selanjutnya, hendaknya dapat memperluas sampel, periode pengamatan yang akan digunakan untuk penelitian selanjutnya.

2. Bagi peneliti selanjutnya diharapkan dapat menambah atau mengganti variabel lain yang secara teori mempunyai pengaruh secara signifikan terhadap mendeteksi kecurangan.

Bagi peneliti selanjutnya dapat menggunakan bahan penelitian ini sebagai dasar penelitian di perusahaan lain.

\section{REFERENCES}

Agustia, Ria. 2014. "Pengaruh kemampuan audit investigatif terhadap efektifitas pelaksanaan prosedur audit dalam pembuktian kecurangan". Skripsi. Medan : Universitas Sumatera Utara. http//repository.usu.ac.id

AICPA.2007.Concideration of fraud in a financial statement audit.AU section 316.New york : PCAOB standards and related rules, hal 7

Amazon.com. Forensic Accounting(9780073526850):Hopwood William, George Young, Jay Leiner : Books, hal 9

Fitriani, Rika. 2012. “ Pengaruh kemampuan auditor investigatif terhadap efektifitas pelaksanaan prosedur audit dalam pembuktian kecurangan 
(fraud)". Skripsi. Medan: Universitas Sumatera Utara. http//repository.usu.ac.id

Ghozali, Imam. 2009. Aplikasi Analisis Multivariate dengan Program SPSS. Semarang: Badan Penerbit Universitas diponegoro. Hal $21,22,23,24,25$, dan 26

Gusnardi. 2012. "Peran forencic accounting dalam pencegahan fraud”. Skripsi. Medan : Universitas Sumatera Utara. http//repository.usu.ac.id

Herlambang.2011. Pengertian audit investigasi.Diakses maret 2007 dari masherla.wordpress: http// masherla.wordpress.com, hal 11

Ikatan Akuntansi Indonesia (IAI).2006. Standar akuntansi keuangan.Jakarta: Salemba Empat, hal 11

Islahuzzaman.2012.Istilah - Istilah Akuntansi \& auditing. Jakarta: Bumi Aksara, hal 6

Narimawati, Umi .2008. Teknik - Teknik Analisis Multivariate untuk Riset Ekonomi. Yogyakarta : Graha Ilmu, hal 17

Narimawati, Umi.2008.Metode Penelitian Kualitatif dan Kuantitatif Teori dan Aplikasi. Bandung : Agung Media hal 17

Riduan Simanjuntak, Ak., MBA, CISA, CIA; "Kecurangan: Pengertian dan Pencegahan"; diunduh dari www.asei.co.id/internal/docs/AseiKecurangan.doc , hal 7

Shodiq, Nur. 2013. "Persepsi auditor terhadap penerapan audit forensik dalam mendeteksi kecurangan penyajian laporan keuangan". Skripsi. Medan : Universitas Sumatera Utara. http//repository.usu.ac.id

Sugiono.2012.Memahami penelitian kualitatif. Bandung : Alfabeta, hal 17 dan 18

Sujarweni, Wiratna V.2015.Sistem Akuntansi.Yogyakarta : Pustaka Baru Press, hal 16

Swarna, Dara Dian. 2012. “ Penerapan akuntansi forensik dan audit investigatif dalam mendeteksi fraud di lingkungan digital". Skripsi. Medan : Universitas Sumatera Utara. http//repository.usu.ac.id

Tuanakotta, Theodorus M. 2010. Akuntansi forensik dan Audit investigatif.Jakarta: Salemba Empat, hal 6,9,11 dan 12

Tuanakotta, Theodorus M.2007.Akuntansi Forensik dan Audit Investigatif.

Jakarta : Salemba Empat, hal 8 
Tuanakotta, Theodorus M.2016. Akuntansi Forensik dan Audit Investigatif. Jakarta : Salemba Empat, hal 7

Tunggal, Amin Widjaja. 2011. Pencegahan dan Pendeteksian Kecurangan. Jakarta : Harvarindo, hal 6 dan 7

Tunggal, Amin Widjaja. 2016. Pencegahan dan Pendeteksian Kecurangan. Jakarta : Harvarindo, hal 6 dan 10

Wind, Ajeng.2016.Forensic accounting.Jakarta : Dunia cerdas, hal 9 dan 10. 